were not inhibitory to rust development. In some experiments, leaf rust races reacted differentially to maleic hydrazide. The authors consider that both nutritional and inhibitory factors may be involved in resistance and host-pathogen specificity.

\section{Tenth Pacific Science Congress}

The tenth Pacific Science Congress is to be held at the University of Hawaii, Honolulu, during August 21-September 6, 1961. The Congress will be divided into nine Sections: Agricultural Sciences; Anthropology and Social Sciences; Biologieal Sciences; Conservation; Forestry ; Geography ; Geophysical Sciences; Public Health and Medical Sciences; Scientific Information. Each Section will include a number of divisions. Three special symposia are being organized: "Man's Place in the Island Ecosystem"; "Science Museums in the Pacific Area"; "Galapagos Islands : a Unique Area for Scientific Investigations". Further information can be obtained from the secretary-general, Mr. Harold J. Coolidge, Tenth Pacific Science Congress, Bishop Museum, Honolulu 17, Hawaii.

\section{University News :}

London

Appointments are announced as follows: $\mathrm{Dr}$. D. R. Cox, reader in statistics at Birkbeck College, to the University chair of statistics tenable at that College; Dr. E. F. Scowen, reader in medicine at St. Bartholomew's Hospital Medical College, to the University chair of medicine tenable at that College; Mr. Arthur Summerfield, lecturer in psychology at University College, to the chair of psychology tenable at Birkbeck College; Dr. Donald Rogers, senior lecturer in physics at University College, Cardiff, to the University readership in chemical crystallography tenable at the Imperial College of Science and Technology from October 1 . Titles within the University of London have been conferred as follows: professor of mathematics, on Dr. K. F. Roth, in respect of his post at University College ; reader in medicine, on Mr. P. H. Sanderson, in respect of his post at St. Mary's Hospital Medical School; professor emeritus of biochemistry, on Prof. W. Robson, on his retirement from the professorship of biochemistry at King's College; reader in mathematics, on Dr. F. A. E. Pirani, in respect of his post at King's College; reader in mathematics, on Dr. S. Raimes, in respect of his post at the Imperial College of Science and Tochnology. Dr. F. A. Goldsworthy was appointed to the readership in applied mathematics at Queen Mary College (see Nature, 189,$22 ; 1961$ ), but was unable to accept the appointment.

\section{Announcements}

THe following awards have been made by the president and council of the Royal Astronomical Society : Gold Medal : Prof. Herman Zanstra, until recently professor of astronomy in the Univensity of Amsterdam, for his work on gaseous nebulæ; Eddington Medal : Prof. Hans A. Bethe, professor of nuclear physics at Cornell University, for his outstanding identification of energy-generating processes in stars.

Mr. J. A. Chaldecott, deputy keeper in the Department of Physics, Science Museum, South Kensington, has been appointed keeper of the Science Library in succession to the late Mr. H. T. Pledge. Mr. G. W. B. Lacey, assistant keeper, has been appointed deputy keeper in the Department of Aeronautics.

Mr. M. A. L. Banks, a managing director of the British Petroleum Co., Ltd., has been appointed a member of the Advisory Council on Research and Development to the Ministry of Power. The Council, which advises the Minister on the scientific aspects of his statutory duties, was recently reconstituted and its terms of reference amended so as to emphasize that its advisory functions cover all aspects of research and development concerned with fuel and power from the laboratory to industrial application.

The Industrial Science Achievement Award of the American Association for the Advancement of Science has been awarded to the Bell Telephone Laboratories, Inc., for its achievements in the field of universal communication during the year 1960 . Among the work mentioned was: long-distance communication by reflecting radio-signals from Echo 1, the world's first electronic telephone switching system, the optical maser and solid state materials.

Applications are invited by St. John's College, Cambridge, for the Kenneth Craik Research Award, which is available for the assistance of persons engaged in postgraduate research, preferably in physiological psychology. The value of the Award will be $£ 450$ a year. Applications should be sent to the Master, St. John's College, Cambridge, so as to reach him not later than April 1, 1961.

A NEW colour magazine, Knowledge, has appeared. It is intended, by an easy appeal, to give children a glimpse of "the strange variety of things that the world has to show", as the editorial states. There is a South American edition too, and similar editions will be forthcoming from other countries ; a cultural exchange of articles is planned. The magazine costs $2 s$. and appears every Monday (Purnell and Sons, Ltd., 37 Hertford Street, London, W.1).

The Royal Society has available for loan to film societies, educational institutions, schools, etc., a $16-\mathrm{mm}$. sound film in colour which runs for about 40 min. entitled "South from Chiloé" at a nominal service charge of two guineas per showing. 'This film tells the story of the Society's expedition to Southern Chile during the period October 1958-February 1959 which went to study the flora and fauna of this little-known region of the world. Requests for hire should be addressed to the Assistant Secretary, Royal Society, Burlington House, Piccadilly, London, W.1.

The Society of Leather Trades' Chemists is organizing a symposium on "The Technology of Drying Fibrous Materials with Particular Reference to Leather" during March 23-24. The symposium will be held in the Physical Chemistry Department, University of Cambridge. Further information can be obtained from G. H. W. Humphreys, 3 The Grove, Radlett, Herts.

A symposium on "Microchemical Techniques" is being organized by the Metropolitan Microchemical Society under the sponsorship of the International Union of Pure and Applied Chemistry. The symposium will be held at the Pennsylvania State University during August 13-18. Further information can be obtained from Mr. Howard J. Francis, jun., c/o Pennsalt Chemicals Corporation, P.O. 4388, Philadelphia 18, Pennsylvania. 